\title{
Reading East of the Berlin Wall
}

\author{
ROAR LISHAUGEN AND \\ JIŘINA ŠMEJKALOVÁ
}

ROAR LISHAUGEN teaches Czech and Slavic studies at the University of Oslo and is the author of articles and essays on Czech literature and on the history of reading in Cold War Central Europe. Beyond a project conducted with Jiřina Šmejkalová, he also examines reading clubs and their role in nineteenthcentury Czech nation building.

JIŘINA ŠMEJKALOVÁ teaches book and cultural studies at Charles University and Palacký University. The author of numerous essays in journals and books, she is also the author of Cold War Books in the "Other" Europe and What Came After (Brill, 2010). Her current project, investigated with Roar Lishaugen, examines the role of paper in totalitarian cultural management during the Cold War.

178

\section{THE END OF THE COLD WAR BROUGHT COUNTLESS CHANGES AND}

\section{CHALLENGES TO EVERYONE EAST OF THE BERLIN WALL. WORDS-BOTH}

printed and spoken - changed their meanings virtually overnight, and texts from the indices librorum prohibitorum ("lists of prohibited books") carefully compiled by Communist authorities began to flood the newly commercialized book market in print runs of hundreds of thousands. "Living in truth" (Havel), and reading in it, suddenly appeared feasible.

A coincidence or not, this major sociopolitical change came with significant changes in the Euro-American humanities and social sciences. The ensuing cultural turn introduced new scholarly perspectives-book studies being but one of many increasingly distinguished fields of study-and encouraged researchers to pursue actors, phenomena, and events previously considered insignificant.

The paradigm shift away from a positivist epistemology on the one hand, and the breakup of the binary Cold War opposition of east and west on the other, paved the way for numerous possibilities. Among them was the promise of unlimited exchange of and access to information, a promise that had stood at the center of all opposition movements in the region during the Cold War and played a vital role in dismantling the command systems. ${ }^{1}$ Without trying to assess the extent to which this promise was fulfilled, our essay asks the question: How do we examine readers and comprehend their reading practices under centrally controlled regimes? We intend to address the methodological challenges we have been facing in the hope that our concerns may contribute to a reevaluation of established accounts of the process of and the value placed on reading.

\section{Print, Bildung, and Change}

Reading occupied a crucial position in the cultural management of the Soviet Union and its satellite states and also played an important role in research on culture conducted in the region. However, this im-

(C) 2019 ROAR LISHAUGEN AND JIŘINA ŠMEJKALOVÁ

PMLA 134.1 (2019), published by the Modern Language Association of America 
portant period in the history of reading east of Berlin is not represented in mainstream scholarship published in English. While intellectual exchanges were hampered by the Iron Curtain, an obvious language barrier stood in their way even after its fall. Moreover, the twentieth century attracts relatively little attention from historians of reading. In fact, a survey of recent histories of reading suggests that their benchmark is the French Revolution not the Russian one (Towheed and Owens; Towheed et al.; Lyons; Cavallo and Chartier).

Since Elizabeth L. Eisenstein's The Printing Revolution (1983), scholars have assumed, somewhat problematically, that print, literacy, and reading as a prerequisite for Bildung reinforce one another in modern societies adhering to the principles of democracy and free markets. This assumption has been associated with, among other things, the Habermasian model of the public sphere and Benedict Anderson's imagined communities, both of which are made possible by print technology. Consequently, there has been a tendency to construct a linear narrative of the history of reading that dovetails with the development of modern statehood.

Moreover, scholarship on Eastern European culture produced both inside and outside the region during the Cold War, which inevitably collides with research on the history of reading, often got trapped in a space dominated by pro- or anti-Soviet ideology (Šmejkalová 83). Reproducing this dichotomous discourse, scholars strongly inclined to give censorship a leading position in approaches to cultural production and reception. Consequently, they tended to see everyone involved in the complex sociocultural dynamics of the time as one of three things: an almighty censor, an oppressed author, or a victimized and manipulated reader. This trend was even more forceful in Eastern Europe than it was in other places shaped by Robert Darnton's "trouble with the history of censorship," which is that censorship "looks so simple: it pits the children of light against the children of darkness" ("Censorship" 40).

The result of this trend was a simplified notion of a totalitarian common reader who was denied access to Michel de Certeau's strategies for creative resistance in everyday life. This reader was nothing like Certeau's readers, who "are travellers; they move across lands belonging to someone else, like nomads poaching their way across fields they did not write" (174). Similarly, Roger Chartier's notion of the "appropriation" of cultural meanings and practices, which conveys a sense of active human agency in relation to available cultural resources and "accentuates plural uses and diverse understandings" (89), does not help us understand a reader of Nikolay Ostrovsky's novel How the Steel Was Tempered, which had a total print run of $36,416,000$ during the Soviet era (Nemirovsky).

Simplistic assumptions about reading in totalitarian systems are somewhat paradoxical, given that reading and readers were supremely important in making and breaking the Soviet-style cultural system. Reading had enormous social, political, and symbolic power. Not just a tool for "enlightening" the population, reading was an agent of social change. According to Evgeny Dobrenko, reading exemplified a central part of Soviet culture, "a political and aesthetic project radically focused on the recipient" (2). Reading also created a fruitful space for mythmaking. Stephen Lovell suggests that of all Soviet cultural myths, none was more resilient than the belief that the Soviet Union had the world's greatest readers (157-58).

For early Soviet authorities, the promotion of reading and, most important, the construction and formation of a reader were part of their overall project of modernization (Šmejkalová 118; Dobrenko 1-41). The population had an exceptionally low literacy rate- only $40.1 \%$ of the combined populations of Ukraine and the Russian Soviet Federative Socialist Republic above the age of 
eight were literate in 1920 (Kenez 73) - and Soviet authorities considered reading crucial for socioeconomic progress even though it had drawbacks. As Elizabeth A. Papazian notes, "the success of the literacy campaign was one of the proudest accomplishments of the Bolshevik Party, but at the same time, the leadership was clearly aware that empowering people in this way might entail risks" (74). In her discussion of Socialist Realism, the doctrine governing all forms of cultural production adopted at the First Soviet Writer's Congress in 1934, she identifies "a governing tension between literacy and legibility, between reading and being read" (75). In other words, there was a conflict between the liberating potential of achieving literacy on the one hand and constraints on what could and should be read on the other. Political doctrines and prescriptions for fictional creative writing made it clear that reading was to serve not as a tool for crafting a critical public sphere and a progressive modern society but rather as a vehicle for social and intellectual leveling.

In the context of the production and reception of books under the system of Soviet command, print did not-and for readers in many parts of the world still does not-represent an instrument of democratization and of universal access to information.

\section{The Uses of the Postcolonial}

Since the early 1920s, Soviet Russia had essentially tried to form new readers, but the goal of Soviet-style authorities in most of the satellite states of Eastern and Central Europe was different. For example, following the Czechoslovak Communist coup d'état of 1948, the victorious political forces faced the task of reforming existing readers. Imposing the Soviet command model of the "book communication circuit" (Darnton, "What" 68) on a highly developed network of private publishers and public libraries and, most im- portant, an almost fully literate population posed a major challenge.

The Soviet powers might be thought of as colonizers trying to impose their model of managing readers and books, and Russian texts in translations certainly "travelled" (in Certeau's sense) all around the satellite states in the region. However, the use of a postcolonial framework to examine texts' journeys to distant places remains highly questionable. $^{2}$ The metaphors of geography, displacement, departure, and arrival acquire rather different connotations in this context than in postcolonial theory, given the different "direction of change" (Sharp 3). Many of the states of the Soviet satellite bloc and even of the USSR (specifically the Baltic states) had, at least since the nineteenth century, considered themselves part of a cohesive, collective European cultural identity denoted by the term the West (see Said). The advancement of a patriotic publishing and reading culture was a significant part of their nation-building mythology. While we cannot uncritically accept the data on high illiteracy rates in Tsarist Russia, particularly those cited in Soviet studies from the 1920s, because these were intended to contrast the backwardness of the previous regime with the progressiveness of the Bolshevik cultural revolution, one point should be stressed. Soviet efforts to expand literacy began with the book communication circuit, which was developed to meet the needs of audiences embedded in the local conventions of oral cultures and was designed to produce and promote texts clear enough to be read by common readers.

This is not to say that these imported or imposed texts were not read in the Soviet satellites. But after 1989 the "decolonized" publishers and readers demonstrated a rather radical split from their former "colonizers." To take just one example of this split: in 1989 books translated into Czech from Russian outnumbered those translated from English two to one, but in 1999 Czech translations 
from English outnumbered those from Russian seventy to one (Wögerbauer et al. 1431).

\section{Decapitalizing the Book}

Scholarly accounts of reading, including those by Richard Hoggart, Richard D. Altick, Robert Escarpit, and Darnton (Forbidden Best-Sellers), have traditionally assumed that a book's social function is inseparable from market forces. One of the few attempts at challenging this assumption, which is deeply embedded in the scholarship on books and reading, can be found in Gordon Johnston's study "What Is the History of Samizdat?"3 Johnston poses the key question: "What happens ... if the overarching rationale for any moment or period in the history of books is not driven or even strongly informed by commercial considerations?" (121).

While Johnston's argument focuses on the production of a dissident textual corpus, part of his argument can also be applied to our consideration of the state control of publishing and reading. Indeed, in the absence of Westernstyle commercial forces, even the official state controlled production of texts entailed the existence of informal exchange networks.

While regulatory and interventionist efforts to target the local book market were part of the former Czechoslovakia's cultural policy at least since the end of World War II (Janáček, Literární), the full transition from privately owned publishing enterprises to government organizations was based on the Soviet model (Šmejkalová 45). The "jsou provždy vyloučeny soukromopodnikatelské výdělečné zájmy" ("eternal elimination of private profitdriven interests") from the local publishing culture was considered key in creating a new, reformed readership (Kopecký 6). The Communist government confiscated the property of all private publishers and declared independent publishing unlawful on 24 March 1949. The established network, consisting of hundreds of economic operators, was forcefully replaced by a fully centralized institutional framework. This process led to the dramatic reduction in the number of titles released. Between 1948 and 1950 alone, the first two years of Communist rule, the number of published titles dropped from 6,640 to 3,797, while the average print run increased from 6,600 to 22,000 per title (Šmejkalová 119). Unsurprisingly, the significantly reduced number of printed titles also made it easier to control and manipulate texts and their readers.

During the period of Communist rule, reading materials were commissioned by entities outside the relation between the reader and the book. These entities claimed a selfassigned legitimacy to represent and determine the interests of the common readers. Adopting the slogan "books into the hands of the people," they completely redefined the roles of all the actors in the command book communication circuit, including editors, printers, distributors, and booksellers. In this newly established circuit, book production and reception no longer involved economically grounded relationships among authors, publishers, and readers. Interrelated agencies were merged to form a collective entity driven by the so-called common interests defined and dictated from above. As a result, it was unclear who held authority in this system, and what competence and above all responsibility meant.

Key to the functioning of this circuit was that its transactions lacked transparency and accountability. Because the relations among the institutional and individual components of the system were no longer clearly defined, new interinstitutional spaces and exchange networks emerged and became rife with corruption. Corruption should be understood in this context not in purely monetary terms but rather in terms of the abuse of the power of the state to grant or deprive people of benefits without being held accountable in any transparent way. In state-controlled publishing this kind of corruption took the form of 
"gifts, barters, loans," paid and unpaid labor, as well as the appropriation of a text by using it to pay for services outside the system of book production, which is common in systems of samizdat production, according to Johnston (121). Most important, readers played an active role in keeping the nonmonetary book economy alive.

Desirable books published in insufficient print runs joined the economy of shortage and its counterpart, the shadow economy (Kornai). Members of the intellectual elite and common readers alike queued up in front of bookstores. Books were kept under the counter for the bookseller's informal social networks or for those who were willing to pay more than the fixed price; a volume of crime fiction-along with a bottle of good liquor-was an efficient tool for bribing one's lawyer or dentist. Using books to pay for services that had nothing to do with textual production was common in both state and alternative publishing. According to Dimitry Pospielovsky, Soviet sailors used to pay Soviet prostitutes with volumes of samizdat (46n4).

\section{Classless Reading}

Our case studies have significantly challenged the questionable assumption about the link between print, reading, and capital in terms of privately owned means of production operating for profit. Certeau argued that reading is "situated at the point where social stratification (class relationships) and poetic operations (the practitioner's constructions of a text) intersect: a social hierarchization seeks to make the reader conform to the "information' distributed by an elite (or semi-elite)" (172). But what happens if reading practices are not driven or even strongly affected by class hierarchization?

Some answers can be found in research on reading that was conducted in the region. The former Soviet Union and its satellite states did not just attempt to experiment with controlling culture centrally but also aimed to produce knowledge about the cultural practices of the population. Although the research projects conducted throughout the region differ in their methodologies, it is safe to argue that they had a shared ideological motive, namely the attempt to provide evidence of the cultured and advanced nature of socialist society and its supremacy over the West. For example, East German researchers tried to set up a distinction between Kaufpropaganda ("buying propaganda") and Lesepropaganda ("reading propaganda") in a largely symbolic competition with West Germany (Sommer et al. 416-17).

Scholars at the Országos Széchényi Könyvtár (National Széchényi Library) in Budapest conducted a large-scale reception study of Mikhail Bulgakov's The Master and Margarita. In Hungary, seven editions of the novel were published between 1969 and 1984, and the novel generated numerous spin-offs, including a radio and a stage production, a pop song, school discussions, and a televised quiz show. The novel became a motif in a church oratorio and in contemporary Hungarian poetry, and some phrases from the novel entered everyday language.

The project used the novel to study how readers communicate with a text. The project's team found that the secret behind the novel's success was that the novel filled a gap, making up for the absence of certain experiences in contemporary Hungarian society. It spurred an interest in transcendental issues, shattered political and ethical taboos, and provided an opportunity for people to articulate and interpret their own life experiences. The team's leader, István Kamarás, made a salient point by suggesting that it was impossible to define the book's readers as a group in traditional sociological terms. What defined Bulgakov's readers was precisely this empty space in their lives, which the text and its multimedia "byproducts" helped them acknowledge and purported to fill (Kamarás 40-42). 


\section{The Hybrid Reader}

The Hungarian researchers did not suggest that the system of book production succeeded in generating classless readers. However, their results do present further challenges to research on reading east of the Berlin Wall. How should we examine and understand the actual practices of communities involved in producing and reproducing the experiment in social and cultural engineering that was the system of Soviet command reading? The methodological challenge is noteworthy, in view of the often very thin and porous line between endorsing and rejecting the normative discourse that dominated the sphere of official publishing and reading. Individual reading experiences are not easily traced and are nearly impossible to inspect retroactively (Lishaugen). Indeed, such experiences were, naturally, country-specific and varied greatly in particular periods of the Cold War and among different strata of the population. Analysis and interpretation of readers' testimonies would also need to take into consideration the fact that the same individual would have read differently in distinct phases of his or her life not just according to education, maturity, or experience but also in relation to the shifting visibility and power of the normative discourse.

Consider the following two perhaps simplified examples. In 1952 a female Czech reader wrote a letter to the editors of the periodical Vlasta, which published Soviet serial novels: "For a long time I didn't know the new Soviet literature. After I read the first Soviet books, which introduced me to fine people, good, courageous people, I fell in love with Soviet reading” (qtd. in Janáček, “The Case”). However, researchers who surveyed readers' preferences based on borrowing records in thirty libraries from 1982 to 1988 discovered their growing indifference to socialist realist fiction and to Soviet literature in translation. In a report that could have been published only after 1989, the researchers concluded that "přes veškerou snahu ideologicky znásilnit kulturu se nepodařilo oktrojovat čtenářům záměry 'normalizátorů”" (“despite all the attempts to rape culture ideologically, [the authorities] have not succeeded at imposing their intentions on readers"; Haman 124).

However, the cultural experiments conducted by the Communist authorities, or by the authorities in other totalitarian regimes, were not carried out to make a significant part of the population feel inferior. They were pursued in the name of "the people" and, consequently, in the name of the common reader. The dominant normative discourse of reading in the command system was derived from early Soviet theories of reading. These saw reading as the collective and more or less passive reception of "truthful" texts whose readers were to make direct links between their practical, everyday experience and the content of the texts (Lishaugen 123). This notion of reading could be found in the guidelines of socialist realism, in which texts had to be relevant and understandable to the working people, include realistic scenes of everyday life, and support the aims of the state and the party (Juraga and Booker 68).

By reading these texts, the powerless were to be elevated to a position of power, and this notion certainly found supporters despite the atrocities that resulted from the practical application of the state and party's cultural policies. Reading's transformation into an important tool of social engineering was based on the assumption that if guided to approaching texts from the perspective of state ideology, readers would be "capable of meeting desired social expectations" (Šmejkalová 116; see Lishaugen 109-10).

Like readers in other sociopolitical contexts, the readers of books produced in the command system made sense of texts by "fitting them within a pre-existing cultural frame" (Darnton, Forbidden Best-Sellers 186-87). But such readers were also fitting 
texts into preexisting categories in terms of their materiality and accessibility. As a Czech research project from the 1960s suggests, traditions and memories of reading, as well as previous reading experiences, played an essential role in this process (Vančura et al. 175-77). In their decisions about what books to buy, readers relied to a high degree on recommendations from friends. Surveys conducted in the 1980s demonstrated the decreasing capacity of the Soviet-style system to satisfy specific readers' and book buyers' demands. According to one study, bookstores in Prague managed to provide only twentyfive percent of the books requested by buyers (Cejp et al. 93). Instead of following the official reading campaigns, designed by the authorities in order to promote proestablishment authors and titles, readers would borrow books from the shelves of their friends' or relatives' private libraries.

Our research has taught us to pay particular attention to the multiplicity of reading practices, because not all readers had the same level of access to the various spheres of textual production. For this purpose we propose the concept of a hybrid reader, who simply was not able to follow "the hottest trends on the market." The hybrid reader had to seek his or her reading material among currently published books and simultaneously use informal social networks to search private libraries for titles published before the Communist takeover in 1948 or during periods of relative political liberty. Avid readers would have tried to gain access to books published by alternative methods such as samizdat. We do not consider samizdat to be just a means to promote an oppositional political and aesthetic agenda but rather a certain type of pirate publishing that resulted from the insufficient supply of books produced by regular means (Šmejkalová 95, 106-08; see Altick). Not only did readers "travel" in the private, public, and alternative domains of book production, but authors did too, as their texts "travelled" in official, samizdat, and exilic spheres of publication. ${ }^{4}$ Thus, what seemed to have defined reading in this specific context was not so much the Soviet-style control of reading but rather the circular, internal mobility of texts and readers within a network that every individual reader had to build according to his or her capacities, needs, social networks, and horizons.

\section{Materiality of Access}

A key lesson of our research in command books and their readers is the urgency with which technical and material processes need to be brought back into consideration, in the light of the contention that nonhuman entities not only are active components of book culture but also should be investigated on a more equal footing with human agency. For us, materiality is not just an attribute such as the "aesthetic of deformation" or "wretched material character" associated with samizdat (Komaromi 616). Along with Barad, whose notion of matter is "not a thing but a doing" (151), our references to materiality are not about isolated or static entities or attributes but about dynamic practices, about processes that produce the fluctuating effect of borders, stability, or barriers. It is in this sense that we want to stress the importance of the materiality of access to printed texts, and not just in the context of extreme cases like those of jailed producers and distributors of samizdat, but in the everyday practices and rituals generated by state-controlled publishing, which, after all, supplied the majority of the population with reading matter. These rituals include queuing up in front of bookstores and making countless journeys to secondhand bookshops where-unlike in the regular stores where books were sold only over the counter-customers were able to scan the shelves and touch and smell the volumes (Šmejkalová 193). The very act of reading, in the sense of looking at a text and deriving meaning from it, was the tip 
of an iceberg and could not be separated from the process of actually acquiring texts. There was nothing guaranteed about being able to pick up a book.

Our own work recently shifted toward investigating the practices, performances, and discourses through which paper worked, to put it in Latourian terms, as an actor in making and breaking the command media book culture. The concern with paper brought our attention to current theoretical debates about the study of material and nonmaterial culture (Preston; Latour; Buchli), new materialism (Parikka; Bennett), and media archeology (Huhtamo and Parikka), despite their focus on digital communication. This is not to oppose the point Darnton made in his review of Ben Kafka's The Demon of Writing, that "the Terror was driven by men, not determined by things" ("Chasing Paper"). Nonetheless, our research resources grew out of the context of the economy of shortage. We would argue that, if the authorities created "terror" by restricting access to the material means of the free exchange of ideas, then it is important to understand how "things" acquired a specific kind of agency in the economy of shortage. It was the need to stop wasting "tolik cenného papíru, jejž bychom dnes potřebovali” ("a valuable amount of paper, so scarce today") that the Communist authorities presented as an argument for not publishing "bezcenných, zbytečných knih a ... škodlivých knih cizí západní produkce” ("valueless, useless and ... dangerous books of foreign Western origin”; Kopecký 6).

Clearly, we are not alone in looking in this direction and finding inspiring allies, for example in the recent analyses of readers' interactions with books in the wider contexts of visual and material culture (Lundblad). Even more important is the emerging discipline of paperwork studies (Kafka; Gitelman): its "choice of paper as an object of study" reveals that "focusing on materiality of texts sheds important new light on our reading practices and social formations" (Senchyne 68).

\section{In Lieu of a Conclusion}

We cannot draw only one lesson from the study of command books and their readers. However, numerous research projects on reading that were conducted in the Soviet Union and its satellite states, particularly during the last decades of the Cold War, pointed toward cracks in the command system's practices of publishing and reading, especially in the notion that reading certain carefully selected and prescribed texts is a means for achieving desirable growth and progress. But these cracks are not those mentioned by Certeau, who describes "reading operations (that) manipulate the reader by insinuating their inventiveness into the cracks in a cultural orthodoxy" (172), nor are they indicative of what Darnton saw in the East German and French ancien régime, whose "administrators of the book trade created enough cracks in their own bureaucracy for unorthodox books to seep into the reading public" ("Censorship" 58). Rather, we would argue that such cracks in the Soviet system were not just anomalies, deviations from normality, but rather inherent parts of any system with totalitarian ambitions, flaws that carry the potential for generating change.

Research on reading in the respective countries revealed growing numbers of nonreaders, decreasing numbers of regular readers, and the "deterioration" or "infantilisation" of their literary tastes (Nagy 7). Some accounts noted that interest in socialist realist novels among library users was dramatically decreasing despite the massive number of translations of contemporary Soviet literature (Haman). Even though print runs of books demanded by reading audiences grew in the late 1980s, the lines of buyers queuing up in front of bookstores in Prague served as further evidence of the incapacity of the command system to satisfy readers. While direct attacks on the content of proregime books were politically impossible in state-owned media 
before 1989, the most courageous critics began reviewing books' materiality and repeatedly referred to the obsolete technologies that produced volumes with loose pages and to the failures of the central warehouses and the distribution company to deliver books on time.

Somewhat paradoxically, by the late 1980s book publishing and reading turned into two more tools with which to question the authority of social and cultural control and the-glorified and clearly overstatedrole that the regulated system of textual production and reception was expected to play. Reading cannot be seen just as a neutral analytic category-it can, and historically did, serve as a tool for manipulation and for subverting social advancement and civic freedom. But what we learn from the analysis of reading east of the Berlin Wall is the good news that banned books do not disappear.

\section{NOTES}

This research was supported in part by grant SVV2018-260483, provided by the Faculty of Arts at Charles University in Prague, Czech Republic.

1. The term command refers to centralized economic systems in which market mechanisms are replaced by a centralized state authority and the allocation of resources is both centrally controlled and politically motivated (Kornai).

2. For a summary of current debates about the potential of postcolonialism methodology to address the concepts and practices of "post-socialism," see Hladík.

3. The originally Russian term samizdat (samsebyaizdat ["to publish oneself"]) refers to the alternative, largely illegal, and thus often prosecuted process of producing and distributing self-published texts in the Soviet Union and its satellite countries. These literary texts, works of nonfiction, and periodicals were mainly handwritten or typed manually (later in the 1980s reproduced unlawfully on photocopiers and duplication machines) and were circulated predominantly by hand among informal networks of dissenters outside the statecontrolled communication circuit (Johnston 122-23).

4. Among the best-known cases are those involving the authors Bohumil Hrabal (1914-97), Václav Havel (1936-2011), and Milan Kundera (1929- ).

\section{Works Cited}

Altick, Richard D. The English Common Reader: A Social History of the Mass Reading Public, 1800-1900. Chicago UP, 1967.

Barad, Karen. Meeting the Universe Halfway: Quantum Physics and the Entanglement of Matter and Meaning. Duke UP, 2007.

Bennett, Jane. Vibrant Matter: A Political Ecology of Things. Duke UP, 2010.

Buchli, Victor, editor. Material Culture: Critical Concepts in the Social Sciences. Routledge, 2004.

Cavallo, Guglielmo, and Roger Chartier, editors. A History of Reading in the West. Polity Press, 1999.

Cejp, M., et al. K některým otázkám budoucího vývoje kultury [On Some Question of the Future Development of Culture]. Ústav pro výzkum kultury, 1980.

Certeau, Michel de. The Practice of Everyday Life. U of California P, 1984.

Chartier, Roger. Forms and Meanings: Texts, Performances, and Audiences from Codex to Computer. $\mathrm{U}$ of Pennsylvania P, 1995.

Darnton, Robert. "Censorship, a Comparative View: France, 1789-East Germany, 1989." Representations, no. 49, Winter 1995, pp. 40-60.

_. "Chasing Paper." The New York Review of Books, 6 Dec. 2012, www.nybooks.com/articles/2012/12/06/ chasing-paper/.

. The Forbidden Best-Sellers of Pre-revolutionary France. HarperCollins Publishers, 1996.

."What Is the History of Books?" Daedalus, vol. 111, no. 3, Summer 1982, pp. 65-83.

Dobrenko, Evgeny. The Making of the State Reader: Social and Aesthetic Contexts of the Reception of Soviet Literature. Stanford UP, 1997.

Eisenstein, Elizabeth L. The Printing Revolution in Early Modern Europe. Cambridge UP, 1983.

Escarpit, Robert. Sociologie de la littérature. PU de France, 1958

Gitelman, Lisa. Paper Knowledge: Toward a Media History of Documents. Duke UP, 2014.

Haman, Aleš. Literatura $z$ pohledu čtenářů [Literature from the Perspective of Readers]. Československý spisovatel, 1991.

Havel, Václav. Living in Truth. Faber and Faber, 1989.

Hladík, Radim. “A Theory's Travelogue: Post-colonial Theory in Post-socialist Space.” Teorie vědy [Theory of Science], vol. 33, no. 4, 2011, pp. 561-90.

Hoggart, Richard. The Uses of Literacy: Aspects of WorkingClass Life, with Special Reference to Publications and Entertainments. Penguin Books, 1957.

Huhtamo, Erkki, and Jussi Parikka, editors. Media Archeology: Approaches, Applications, and Implications. $\mathrm{U}$ of California P, 2011. 
Janáček, Pavel. "The Case of Comrade Anna: The Czech Mass Reader and His Transcription of Socialist Realism." Presented at the Institute for Czech Literature, Academy of Sciences of the Czech Republic, 19 Jan. 2017, Prague. Unpublished manuscript.

_. Literární brak: Operace vyloučení, operace nahrazení, 1938-1951 [Literary Trash: Operation of Exclusion, Operation of Replacement, 1938-1951]. Host, 2004.

Johnston, Gordon. "What Is the History of Samizdat?" Social History, vol. 24, no. 2, 1999, pp. 115-33.

Juraga, Dubravka, and M. Keith Booker. Socialist Cultures East and West: A Post-Cold War Reassessment. Praeger, 2002.

Kafka, Ben. The Demon of Writing: Powers and Failures of Paperwork. Zone Books, 2012.

Kamarás, István. Follow Me, Reader! Reception, Interpretation and Influence of Bulgakov's Master and Margarita in Hungary. Országos Széchényi Könyvtár, 1985.

Kenez, Peter. The Birth of the Propaganda State: Soviet Methods of Mass Mobilization, 1917-1929. Cambridge UP, 1985.

Komaromi, Ann. "The Material Existence of Soviet Samizdat." Slavic Review, vol. 63, no. 3, 2004, pp. 597-618.

Kopecký, Václav. "Projev ministra informací a osvěty na schůzi Národního shromáždění 24. března 1949” [Speech of the Minister of Information and Enlightenment at the Meeting of the National Assembly 24 March 1949]. Kniha do rukou lidu [Books into the Hands of the People], by Kopecký et al., Ministerstvo informací a osvěty, 1949, pp. 5-14.

Kornai, János. Economics of Shortage. North-Holland, 1980.

Latour, Bruno. Reassembling the Social: An Introduction to Actor-Network-Theory. Oxford UP, 2005.

Lishaugen, Roar. "Incompatible Reading Cultures: Czech Common Readers and the Soviet Mass Reader Concept in the Early 1950s." Scando-Slavica, vol. 60, no. 1, 2014, pp. 108-27.

Lovell, Stephen. The Russian Reading Revolution: Print Culture in the Soviet and Post-Soviet Eras. Palgrave Macmillan, 2000.

Lundblad, Kristina. Bound to Be Modern: Publishers' Clothbindings and the Material Culture of the Book, 1840-1914. Oak Knoll Press, 2015.

Lyons, Martyn. A History of Reading and Writing in the Western World. Palgrave Macmillan, 2010.
Nagy, Attila. "On the Reading Culture of the Ten to Fourteen Year Olds." Reading Research in the Centre for Library Science and Methodology, 1981-85, by Nagy et al., National Széchényi Library Centre for Library Science and Methodology, 1986, pp. 5-10.

Nemirovsky, Evgeny. “Подводя итоги ХХ столетия: книгоиздание Бестселлер - детище рекламы” [To Sum Up the Twentieth Century: Bestseller Is a Brainchild of Advertising]. KompyuArt, no. 3, 2000, compuart.ru/ article/8496.

Papazian, Elizabeth A. "Literacy or Legibility: The Trace of Subjectivity in Soviet Socialist Realism." The Oxford Handbook of Propaganda Studies, edited by Jonathan Auerbach and Russ Castronovo, Oxford UP, 2013, pp. 63-86.

Parikka, Jussi. Insect Media: An Archaeology of Animals and Technology. $\mathrm{U}$ of Minnesota P, 2010.

Pospielovsky, Dimitry. "From Gosizdat to Samizdat and Tamizdat." Canadian Slavonic Papers, vol. 20, no. 1, 1978, pp. 44-62.

Preston, Beth. A Philosophy of Material Culture: Action, Function, and Mind. Routledge, 2013.

Said, Edward W. Orientalism. Routledge and Kegan Paul, 1978.

Senchyne, Jonathan. "Paper Nationalism: Material Textuality and Communal Affiliation in Early America." Book History, no. 19, 2016, pp. 66-85.

Sharp, Joanne. Geographies of Postcolonialism. Sage, 2008.

Šmejkalová, Jiřina. Cold War Books in the "Other" Europe and What Came After. Brill, 2011.

Sommer, Dietrich, et al. Funktion und Wirkung: Soziologische Untersuchungen zur Literatur und Kunst. Aufbau Verlag, 1978.

Towheed, Shafquat, et al., editors. The History of Reading. Routledge, 2010.

Towheed, Shafquat, and W. R. Owens, editors. International Perspectives, c. 1500-1990. Palgrave Macmillan, 2011. Vol. 1 of The History of Reading.

Vančura, Dalibor, et al. Jak se čte na vesnici [What People Read in the Country]. Orbis, 1969.

Wögerbauer, Michael, et al. V obecném zájmu: Cenzura a sociální regulace literatury v moderní české kultuře, 1749-2014 [In the Public Interest: Censorship and Social Regulation of Literature in Modern Czech Culture, 1749-2014]. Vol. 2, Academia, 2015. 